\title{
Determinants of Profitability: A Case Study of Listed Manufacturing Companies in Sri Lanka
}

\author{
A.Nishanthini \& Nimalathasan, B \\ University of Jaffna, Jaffna, Sri Lanka \\ bnimalathasan@yahoo.com
}

\begin{abstract}
The main objective of the study is to determine the profitability of listed manufacturing companies in Sri Lanka. In order to meet the objectives of the study, data were collected from secondary sources mainly from financial report of the selected companies, which were published by Colombo stock exchange in Sri Lanka. The results revealed that the profitability of manufacturing companies is less satisfactory. On the basis of result and analysis, selected manufacturing companies has different ranking based on each profitability indicators such as Gross Profit Ratio (GPR), Operating Profit Ratio (OPR), Net Profit Ratio (NPR), Return on Investment (ROI), and Return on Capital Employed (ROCE). Based on the Gross Profit Ratio, Operating Profit Ratio, Net Profit Ratio, ROYAL CHERAMIC PLC is at first whereas CHEVRON LUBRICANTS PLC is at first based on ROI, ROCE. Outcome of the study is beneficial to academicians, policy makers, practitioners and so on.
\end{abstract}

\section{Introduction}

Profit is the primary objective of a business (Nimalathasan, 2009). In point of view of the heavy investment which is necessary for the success of most enterprises. Profit in the accounting sense tends to become a long term objective which measures not only the success of the product, but also of the development of the market for it. It is determined by matching revenue against cost associated with it. Only those costs are placed against revenue, which have contribution in the generation of such revenue. An enterprise should earn profits to survive and grow over a long period of time. It provides evidence concerning the earnings potential of a company and how effectively a firm is being managed. If the enterprise fails to make profit. Capital invested is eroded and if this situation prolongs the enterprise ultimately ceases to exist.
Profit and profitability are two different terms. Profit means as an absolute measure of earning capacity, while profitability is relative measure of earning capacity. Profit is defined by Iyer (1995) as "excess of return over outlay" (Nimalathasan, 2009) while profitability is defined as "the ability of given investment to earn a return from its use'. The words profitability is composed of two words profit and ability. The word profit has already been defined but the meaning of profit differs according to the use and purpose of the enterprise to earn the profits. Thus the word profitability may be defined as the ability of given investment to earn a return from its use.

Profitability ratios measure the firm's ability to generate profits and central investment to security analysis, shareholders, and investors. Profitability is the primary measure of the overall success of enterprise. The analysis of profitability ratios is important for the 
shareholders, creditors, prospective investors, bankers and government alike.

\section{Literature Review}

Nimalathasan (2009) mentioned that the profit is the primary objective of a business, which measures not only the success of a product, but also of the development of the market for it. Further profit is the report card of the past, the inventive gold star for the future.

Weidenfeld \& Nicholson (1970) concerned that the profit as a reward to owner of the capital but with the return to capital as an objective of a firm's activities. Velnamby \& Nimalathasan (2009) noticed the profitability will provide more accurate view of the firm's performance. Pandy (1979) indicated that recent experience in countries with totally planned economies indicated that economists are probably right in emphasizing the importance of overall profitability as a criterion for the efficient operation of an enterprise.

Weston (1978) declared that the profit is use to test the efficiency and use to measure the control and worth of the investment to the owners, margin of safety to the creditors, source of extreme benefits to the employees, to the Government a measure of taxable capacity and the basis of legislative action, to the country profits are an index of economic progress, national income generated and rise in the standard of living.

On the other hand, welstedt (1980) in his book entitled "state manufacturing enterprises in a Mixed Economy: Turkish case stated that profitability of an enterprise can be ascertained, if profit is analyzed in terms of sales and investment. Schmalensee (1987) mentioned that to determinacy of systematic changes in intraindustry profitability occurred over time so as to distinguish between an efficiency story and collusion story about why concentrated industries had higher profit rates than other industries, and also he found that large firms in general were higher profitable than small firms within the same industry

Velnampy \& Nimalthasan (2007) pointed out that sales are positively associated with profitability ratios except return on investment, and numbers of depositors are negatively correlated with the profitability ratios except return equity, likewise number of advances to the return on investment, and return on average assets in Bank of Ceylon. Sexton \& Kasarda (2000) found that firm profitability was correlated with sustainable growth, while Chandler and Jensen (1992) found that sales growth and profitability were not correlated.

Based on the above literatures, we can say that various studies have been done on this area, but a detailed and comprehensive study has not yet been conducted in manufacturing companies in Sri Lanka. Hence, the present study is initiated to determine the profitability of listed manufacturing companies in Sri Lanka with five (05) year accounting period from 2006 to 2010.

\section{Objectives}

The main objective of the study is to determine the profitability of manufacturing companies. To achieve main objective, the following specific objectives are taken for the study purpose.

- To compare the profitability

- To recognize the profitability.

\section{Material and Methods}

\section{Scope}

The scope of the study is listed manufacturing companies on Colombo stock exchange (CSE), Sri Lanka. Thirty one companies are listed under manufacturing sectors. Hence, out of thirty one, 
only ten companies are selected for the study purpose as purposively such as:

1. ABANS ELECTRICALS PLC

2. ACME PRINTING \& PACKING PLC

3. CENTRAL INDUSTRIAL PLC

4. ACL CABLE PLC

5. ACL PLASTIC PLC

6. LANKA ALUMINUM INDUSTRIAL PLC

7. CHEVRON LUBRICANTS LANKA PLC

8. KALANI CABLES PLC

9. LANKA CERAMIC PLC

10. ROYAL CERAMIC LANKA PLC.

\section{Data sources}

In order to meet the objectives of the study, data are collected from secondary sources mainly from financial report of the selected companies, which were published by Colombo stock exchange in Sri Lanka.

\section{Measures}

Secondary data are used to measure the indicators which are related to profitability. Here indicators of profitability such as Gross profit ratio(GPR); Operating profit ratio (OPR); Net profit ratio (NPR); Return on investment (ROI); Return on equity (ROE); Return on capital employed (ROCE) are taken into account for the study.

\section{Reliability and validity of the Data}

Secondary data for the study are drawn audit accounts (i.e., income statements and balance sheets) of the concerned companies therefore; these data may be considered reliable for the purpose of the study.

\section{Results and Discussion}

Comparison of profitability of the manufacturing companies is measured in terms of the important ratios such as

Gross Profit Ratio (GPR)

Operating Profit Ratio (OPR)

Net Profit Ratio (NPR)

Return on Investment (ROI)

Return on Capital Employed (ROCE)

\section{Gross Profit Ratio}

Gross profit percentage that can be earned from the net sales. That is the relationship between the sales and the gross profit. It depicts the purchasing efficiency of an enterprise. The higher the gross profit ratio, the better the purchasing efficiency of the enterprise and also a high ratio of gross profits to sales is a sign of good management as it implies that the cost of production of the firm is relatively low. But a relationship low gross margin is definitely a danger signal. The gross profit ratios of the companies for the study period have been shown in the table 1.

Table-1 shows that the gross profit of the ABANS, ACME, CENTRAL INDUSTRIAL, ACL CABLE, ACL PLASTIC, LANKA ALUMINIUM, CHEVRON LUBRICANTS, KALANI KEBLES, LANKA CHARAMIC, and ROYAL CHERAMIC during the period 2006 to 2010. This showed an upward trend of ABANS, ACME, CENTRAL INDUSTRIAL, CHEVRON LUBRICANTS, LANKA CHERAMIC, and ROYAL CHERAMIC during the period from 2007 to 2010; at the same time rest of the companies' shows down ward and flexible trend. It is not a good sign for the company. 
Table 1: Gross Profit Ratio of the selected Companies (in \%)

\begin{tabular}{|l|c|c|c|c|c|c|c|c|}
\hline \multicolumn{1}{|c|}{ NAME OF THE COMPANY } & 2006 & 2007 & 2008 & 2009 & 2010 & TOTAL & AVG & SD \\
\hline ABANS & 11.33 & 9.74 & 11.31 & 11.83 & 13.78 & 57.99 & 11.60 & 1.45 \\
\hline ACME & 21.08 & 21.4 & 23.18 & 25.3 & 24.01 & 114.97 & 22.99 & 1.77 \\
\hline CENTRAL INDUSTRIAL & 25.48 & 23.94 & 26.89 & 26.15 & 30.00 & 132.46 & 26.49 & 2.24 \\
\hline ACL CABLE & 25.13 & 26.72 & 17.36 & 14.64 & 15.8 & 99.65 & 19.93 & 5.58 \\
\hline ACL PLASTIC & 12.13 & 7.95 & 9.14 & 7.93 & 16.06 & 53.21 & 10.64 & 3.48 \\
\hline LANKA ALUMINIUM & 8.99 & 9.72 & 8.34 & 9.17 & 10.05 & 46.27 & 9.254 & 0.66 \\
\hline CHEVRON LUBRICANTS & 26.47 & 23.87 & 23.89 & 35.62 & 32.15 & 142.00 & 28.40 & 5.26 \\
\hline KALANI CABLES & 20.31 & 23.69 & 16.46 & 16.56 & 20.93 & 97.95 & 19.59 & 3.09 \\
\hline LANKA CHERAMIC & 25.47 & 24.56 & 23.01 & 23.17 & 24.33 & 120.54 & 24.11 & 1.02 \\
\hline ROYAL CHERAMIC & 40.25 & 40.06 & 42.37 & 43.92 & 47.59 & 214.19 & 42.84 & 3.10 \\
\hline
\end{tabular}

This is perhaps due to competition in the market and slow growth in the economy of the country. The average gross profit ratio of ROYAL CHERAMIC is $42.84 \%$, which is high percentage compare with other companies, which shows about the companies' high performance of gross profit earning, on the other hand ABANS, ACL PLASTIC, ACL CABLE, LANKA ALUMINIUM and KALANI CABLELS have to improve their performance immediately in future. ACL CABLE, CHEVRON LUBRICANTS have highest variation of gross profit over the years (highest variation over the year is $5.59 \%$ ). It is the good sign for these companies, because whish is in safety position that mean both companies showing increasing trend after 2008, which speaks about the stability of gross profit earning of this companies.

\section{(B). Operating Profit Ratio}

Operating profit ratio is important ratios that explain the changes in the net profit margin ratio. Operating profits refers to the profit of an enterprise. This is obtained after deducting all operating expenses from gross profit. Operating expenses include all administration, selling and distribution expenses but not the expenses borrowing funds and taxes paid to the government. Therefore it represents the overall earnings of an enterprise and one can get a clear idea about the efficiency of an enterprise from its operating profit ratio. The operating profit ratio, the better is the overall efficiency of the enterprise. Weaton \& Brigham (1969) suggested that $4 \%-6 \%$ of operating profit is considered norm for the purpose of comparison and control. The operating profit ratios of the sample companies are shown in table-2.

According to the table-2, many companies out of selected company's operating profit other than LANKA CHERAMIC, CENTRAL INDUSTRIAL showed a downward and more complex flexible trend. This showed effort of the management to control operating expenses had been more or less successful, but in LANKA CHERAMIC'S operating profit suddenly decrease from 2007 to 2008, and then showed upward from 2008 to 2010, at the same time CENTRAL INDUSTRIAL showed an increasing trend from 2006 to 2008 then suddenly decrease to $9.63 \%$ in 2009 after then in 2010 increase to $12.99 \%$ but all the companies average operating profit ratios highest percentage than suggested in above (4\%-6\%). ACL CABLE shows the highest standard 
deviation of $6.85 \%$ of operation profit than other companies operating standard deviation. And also CHEVRON LUBRICANTS, LANKA CHERAMIC, RAYAL CHERAMIC, ACL PLASTIC, ACME indicate convenient standard deviation of operation profit. It indicates extremely desirable position. It helps to ascertain the operating efficiency of the management.

Table 2: Operating Profit Ratio of the selected Companies (in \%)

\begin{tabular}{|l|c|c|c|c|c|c|c|c|}
\hline $\begin{array}{c}\text { NAME OF THE } \\
\text { COMPANY }\end{array}$ & 2006 & 2007 & 2008 & 2009 & 2010 & TOTAL & AVG & SD \\
\hline ABANS & 4.34 & 4.84 & 5.16 & 4.67 & 8.44 & 27.45 & 5.49 & 1.68 \\
\hline ACME & 11.85 & 12.55 & 10.67 & 15.12 & 0.89 & 51.08 & 10.22 & 5.46 \\
\hline CENTRAL INDUSTRIAL & 9.76 & 9.85 & 10.03 & 9.63 & 12.99 & 52.26 & 10.45 & 1.43 \\
\hline ACL CABLE & 19.34 & 20.21 & 10.73 & 6.05 & 6.44 & 62.77 & 12.55 & 6.86 \\
\hline ACL PLASTIC & 11.68 & 6.63 & 9.23 & 7.72 & 15.67 & 50.93 & 10.19 & 3.61 \\
\hline LANKA ALUMINIUM & 4.34 & 5.57 & 4.65 & 4.48 & 4.53 & 23.57 & 4.71 & 0.49 \\
\hline CHEVRON LUBRICANTS & 16.96 & 15.94 & 15.56 & 25.83 & 23.94 & 98.23 & 19.65 & 4.86 \\
\hline KALANI CABLES & 12.79 & 16.42 & 7.41 & 6.79 & 9.11 & 52.52 & 10.50 & 4.05 \\
\hline LANKA CHERAMIC & 14.21 & 15.56 & 11.26 & 13.38 & 17.15 & 71.56 & 14.31 & 2.23 \\
\hline ROYAL CHERAMIC & 23.69 & 22.22 & 28.56 & 25.63 & 31.08 & 131.18 & 26.24 & 3.60 \\
\hline
\end{tabular}

\section{Net Profit Ratio}

This ratio shows the final result or net profit after making a sale. The earnings in terms of sales can be assesses through the profit margin ratio which is calculated by dividing the earnings before interest and taxes by sales. This ratio is widely used as measure of overall profitability and is very useful to proprietors. There is also no fixed norm of judging the net profit ratio. But Mohsim (1970) considered that a profit margin ratio which $4 \%$ to $6 \%$ is termed as the standard norm for any industrial enterprise. The net profit ratios of the sample companies are shown in table-3.

Table 3: Net Profit Ratio of the selected Companies (in \%)

\begin{tabular}{|l|r|r|r|r|r|r|r|r|}
\hline \multicolumn{1}{|c|}{ Name of the company } & \multicolumn{1}{c|}{2006} & \multicolumn{1}{c|}{2007} & \multicolumn{1}{c|}{2008} & \multicolumn{1}{c|}{ A009 } & \multicolumn{1}{c|}{ S010 } & \multicolumn{1}{l|}{ TOTAL } & AVG & \multicolumn{1}{l|}{ SD } \\
\hline ABANS & 1.38 & 1.2 & 0.39 & 1.36 & 2.79 & 7.12 & 1.42 & 0.86 \\
\hline ACME & 2.23 & 2.98 & -0.1 & -0.67 & 0.84 & 5.28 & 1.05 & 1.54 \\
\hline CENTRAL INDUSTRIAL & 6.15 & 5.38 & 5.7 & 5.04 & 7.68 & 29.95 & 5.99 & 1.02 \\
\hline ACL CABLE & 12.43 & 11.33 & 3.69 & 2.02 & 0.76 & 30.23 & 6.05 & 5.44 \\
\hline ACL PLASTIC & 7.41 & 2.92 & 2.37 & 2.76 & 9.64 & 25.1 & 5.02 & 3.30 \\
\hline LANKA ALUMINIUM & 1.17 & 2.4 & 1.47 & 1.35 & 1.31 & 7.7 & 1.54 & 0.49 \\
\hline CHEVRON LUBRICANTS & 12.59 & 10.48 & 10.97 & 17.2 & 15.85 & 67.09 & 13.42 & 2.98 \\
\hline KALANI CABLES & 10.23 & 10.64 & 3.86 & 16.56 & 4.26 & 45.55 & 9.11 & 5.25 \\
\hline LANKA CHERAMIC & 8.57 & 10.5 & 8.16 & 6.25 & 17.15 & 50.63 & 10.13 & 4.207 \\
\hline ROYAL CHERAMIC & 24.03 & 12.68 & 17.58 & 13.84 & 21.66 & 89.79 & 17.96 & 4.88 \\
\hline
\end{tabular}


According to the table- 3 the net profit ratio of CENTRAL INDUSTRIAL and ACL PLASTIC showed increasing trend during the year from 2007 to 2010. At the same time ACL CABLE and LANKA ALUMINIUM showed decreasing trend. On the other hand other companies within selected companies shows flexible trend from 2006 to 2010, even though average net profit ratio of ROYAL CHERAMIC was $17.96 \%$. It was a higher value compare than others and also standard deviation of $4.88 \%$ indicate extremely attractive position. ACL CABLE's standard deviation was $5.44 \%$ while showing increasing trend over the years it indicates that the companies stable position. However other companies have to improve their performance in future.

\section{Return on Investment}

The most commonly used measure of profitability is to relate the profit output with the capital input and thus compute the rate of return on capital investment. This rate is the end profit of a series of quantitative variables representing different interconnected and interdependent factors of business operations. The return on investment is equal to the profit margin on sales multiplied by the investment. Weston \& Brigham (1969) suggested that a return of $13 \%$ to $15 \%$ on net worth should be considered as standard for industrial enterprises. The return on investment of the selected companies is given in table -4 .

Table 4: Return on Investment of the selected Companies (in \%)

\begin{tabular}{|l|r|r|r|r|r|r|r|r|}
\hline NAME OF THE COMPANY & \multicolumn{1}{c|}{2006} & \multicolumn{1}{c|}{2007} & \multicolumn{1}{c|}{2008} & \multicolumn{1}{c|}{2009} & \multicolumn{1}{c|}{2010} & \multicolumn{1}{l|}{ TOTAL } & \multicolumn{1}{c|}{ AVG } & \multicolumn{1}{l|}{ SD } \\
\hline ABANS & 8.69 & 9.38 & 9.32 & 8.07 & 13.34 & 48.80 & 9.76 & 2.07 \\
\hline ACME & 13.52 & 14.24 & 8.49 & 13.70 & 0.82 & 50.77 & 10.15 & 5.71 \\
\hline CENTRAL INDUSTRIAL & 43.19 & 16.01 & 16.46 & 13.51 & 16.49 & 105.66 & 21.13 & 12.39 \\
\hline ACL CABLE & 19.46 & 24.67 & 13.07 & 6.89 & 5.80 & 69.89 & 13.98 & 8.09 \\
\hline ACL PLASTIC & 15.25 & 7.23 & 10.27 & 9.03 & 18.96 & 60.74 & 12.15 & 4.83 \\
\hline LANKA ALUMINIUM & 10.30 & 14.8 & 12.33 & 12.04 & 9.89 & 59.36 & 11.87 & 1.95 \\
\hline CHEVRON LUBRICANTS & 37.60 & 48.18 & 43.66 & 88.68 & 67.18 & 285.3 & 57.06 & 20.85 \\
\hline KALANI CABLES & 14.60 & 23.19 & 9.77 & 9.77 & 11.64 & 68.97 & 13.79 & 5.61 \\
\hline LANKA CHERAMIC & 14.61 & 15.70 & 11.96 & 12.41 & 15.92 & 70.6 & 14.12 & 1.84 \\
\hline ROYAL CHERAMIC & 16.65 & 14.91 & 17.47 & 15.47 & 21.33 & 85.83 & 17.16 & 2.59 \\
\hline
\end{tabular}

Above table-4 shows that ABANS, ACME, ACL PLASTIC, LANKA ALUMINIUM were not satisfactory level during the period from 2006 to 2010, which showed a flexible trend. It indicates remarkable in the stability position of these companies. From the above table we can found that all companies ROI's trends are not in a stable position out of LANKA CHERAMIC and ROYAL CHERAMIC. CHEVRON LUBRICANTS's standard deviation is $20.85 \%$.
It was high percentage with compare than other companies. It expresses the companies' volatility position. It is the noteworthy in the stability position.

\section{Return on Capital Employed}

This is an important ratio. It shows how much return is being generated for every rupee invested in the business. This is calculated by dividing net profit after interest and taxes by 
capital invested and quotient is expressed in terms of percentage. Capital employed represents the sum of net tangible fixed assets and net current assets. A return of $1 \%$ to $12 \%$ on capital employed may be considered standard norm for industrial undertaking. Return on capital employed of selected companies is given in table-5.

Table 5: Return on Capital Employed of the selected Companies (in \%)

\begin{tabular}{|c|c|c|c|c|c|c|c|c|}
\hline $\begin{array}{lll}\text { NAME OF } & \text { THE } \\
\text { COMPANY } & \\
\end{array}$ & 2006 & 2007 & 2008 & 2009 & 2010 & TOTAL & AVG & SD \\
\hline ABANS & 26.22 & 46.82 & 31.07 & 31.26 & 83.98 & 219.35 & 43.87 & 23.73 \\
\hline ACME & 50.39 & 45.5 & 19.59 & 34.32 & 2.27 & 152.07 & 30.41 & 19.69 \\
\hline $\begin{array}{l}\text { CENTRAL } \\
\text { INDUSTRIAL }\end{array}$ & 20.45 & 23.98 & 19.94 & 17.32 & 19.43 & 101.12 & 20.22 & 2.41 \\
\hline ACL CABLE & 38.78 & 52.36 & 29.15 & 13.68 & 11.32 & 145.29 & 29.05 & 17.23 \\
\hline ACL PLASTIC & 18.11 & 11.15 & 20.19 & 15.08 & 23.89 & 88.42 & 17.68 & 4.86 \\
\hline LANKA ALUMINIUM & 24.33 & 30.41 & 30.98 & 25.21 & 26.67 & 137.6 & 27.52 & 3.02 \\
\hline $\begin{array}{l}\text { CHEVRON } \\
\text { LUBRICANTS }\end{array}$ & 74.36 & 81.5 & 64.38 & 91.75 & 91.34 & 403.33 & 80.66 & 11.64 \\
\hline KALANI CABLES & 25.2 & 35.53 & 17.28 & 13.6 & 19.93 & 111.54 & 22.30 & 8.51 \\
\hline LANKA CHERAMIC & 56.72 & 60.85 & 18.7 & 20.49 & 23.19 & 179.95 & 35.99 & 20.92 \\
\hline ROYAL CHERAMIC & 23.92 & 21.61 & 24.56 & 23.74 & 30.36 & 124.19 & 24.84 & 3.28 \\
\hline
\end{tabular}

From the table-5 it is found that ROCE of selected companies of various years was not satisfactory but it showed a decreasing trend of ACL CABLE, ACME for the period from 2009 to 2010 and an upward trend in other companies. Still all selected companies have not maintained a satisfactory rate of ROCE. According to the variation all companies shows diverse rate of variation so, companies may be considered tolerable. It is not a good one to these companies, to prevail over these; the companies should take good trial. Then only they can improve in future.

Table-6 shows that average of profitability indicators for selected companies. ROYAL CERAMIC indicates high percentage of industry average than other companies' industry average except average ROI and average ROCE. And also CHEVRON LUBRICANTS shows higher industry average than other companies' industry average in average ROI and average ROCE. CHEVRON LUBRICANTS should be considered as satisfactory as its indicators of profitability higher than the industry average. ACL PLASTIC and LANKA ALUMINIUM have not been able to attain the industry average. On the other hand another companies out of CHEVRON LIBRICANTS from selected companies, have not been able to attain the industry average in any one or more than one profitability indicators. But these companies have succeeded to attain the standard norm for any one or more than one ratios, as a result its profitability may be considered to some extent satisfactory. 
Table 6: Average Profitability Ratio of the Selected Companies (in \%)

\begin{tabular}{|l|c|c|c|c|c|}
\hline \multicolumn{1}{c|}{$\begin{array}{c}\text { NAME } \\
\text { OF THE }\end{array}$} & $\begin{array}{c}\text { AVERAGE } \\
\text { GROSS } \\
\text { PROFIT } \\
\text { RATIO }\end{array}$ & $\begin{array}{c}\text { AVERAGE } \\
\text { OPERATING } \\
\text { PROFIT } \\
\text { RATIO }\end{array}$ & $\begin{array}{c}\text { AVERAGE } \\
\text { NET } \\
\text { PROFIT } \\
\text { RATIO }\end{array}$ & $\begin{array}{c}\text { AVERAGE } \\
\text { RETURN ON } \\
\text { INVESTMENT }\end{array}$ & $\begin{array}{c}\text { AVERAGE } \\
\text { RETURN ON } \\
\text { CAPITAL } \\
\text { EMPLOYED }\end{array}$ \\
\hline ABANS & 11.59 & 5.49 & 1.42 & 9.76 & 43.87 \\
\hline ACME & 22.99 & 10.21 & 1.05 & 10.15 & 30.41 \\
\hline CENTRAL INDUSTRIAL & 26.49 & 10.45 & 5.99 & 21.13 & 20.22 \\
\hline ACL CABLE & 19.93 & 12.55 & 6.04 & 13.97 & 29.05 \\
\hline ACL PLASIC & 10.64 & 10.18 & 5.02 & 12.14 & 17.68 \\
\hline LANKA ALUMINIUM & 9.25 & 4.71 & 1.54 & 11.87 & 27.52 \\
\hline CHEVRON & 28.40 & 19.64 & 13.41 & 57.06 & 80.66 \\
\hline LUBRICANTS & 19.59 & 10.50 & 9.11 & 13.79 & 22.31 \\
\hline KALANI CABLES & 24.11 & 14.31 & 10.12 & 14.12 & 35.99 \\
\hline LANKA CHERAMIC & 42.84 & 26.23 & 17.95 & 17.16 & 24.83 \\
\hline ROYAL CHERAMIC & 21.58 & 12.43 & 7.16 & 18.18 & 33.25 \\
\hline INDUSTRY AVERAGE & & & &
\end{tabular}

\section{Conclusion}

According to Walker (1974) the return on Investment should be considered as the best measure of profitability, father In view of above, it can be concluded that the profitability of manufacturing companies is less satisfactory. On the basis of result and analysis, selected manufacturing companies has different ranking based on each profitability indicators such as GPR, OPR, NPR, ROI, and ROCE? Based on the GPR, OPR, NPR, ROYAL CHERAMIC is at first whereas CHEVRON LUBRICANTS is at first based on Return on Investment, Return on Capital Employed.

\section{Limitation of the study}

The study covered 10 manufacturing companies, which is listed under CSE in Sri Lanka, in order to measure and compare the profitability.

The study has been conducted during the period from 2006 to 2010. Any change made after this period has not been covered in this study.

\section{References}

Annual Report (2010), Abans Electricals Plc.

Annual Report (2010), Chevron Lubricants Lanka Plc.

Annual Report (2010), ACME Printing \& packing Plc.

An inter \& intra comparison of AMBEE \& IBN SINA Companies Ltd,

Annual Report (2010), ACL Cables Plc.

Annual Report (2010), ACL Plastic Plc.

Annual Report (2010), Central Industries Plc.

Annual Report (2010), Kalani Cables Plc.

Annual Report (2010), Lanka Aluminum industries Plc.

Annual Report (2010), Lanka Ceramic Plc. 
Annual Report (2010), Royal Ceramic Lanka listed manufacturing Companies in Sri Lanka, Plc.

Journal of IPM Meerut, 6:59-69.

Chandler,G.N., \& Jensen.D.A.(1992).Gauging Velnamby,T., \& Nimalathasan,B. performance in emerging business: longitudinal (2007).Organizational Growth and Profitability: Economic and Administrative series, 3:139-148. A case study

Evidence and growth pattern analysis.

Velnamby,T., \& Nimalathasan,B.(2008). Firm

Nimalathasan.B. (2009). Profitability of listed pharmaceutical companies in Bangladesh:

Pandey,I.M.,(1979).Financial management, New Delhi, Vikas Publishing Ohu:443.

Size and Abstracts of research papers, Jaffna science Association, and $15^{\text {th }}$ annual session, Jaffna, Sri Lanka, 15(1):74

Walker, R.W.,(1974).Essential of financial Sexton,D.L., \& Kasarda,J.D.,(2000).The state of Management. $2^{\text {nd }}$ edition, Prentice Hall of India the art of entreprenurship.Boston:Pws-Kent (eds):341-357.

Subramaniyam, A., \& Nimalathasan, B. (2009). Measurement of operational performance Through ratio analysis: A Case study of selected 